\title{
Comparison of the macroparasite communities of wild and stocked brown trout (Salmo trutta L.) in the west of Ireland
}

\author{
C. J. BYRNE ${ }^{1 *}$, C. V. HOLLAND ${ }^{1}$, R. POOLE ${ }^{2}$ and C. R. KENNEDY ${ }^{3}$ \\ ${ }^{1}$ Department of Zoology, University of Dublin Trinity College, Dublin 2, Ireland \\ ${ }^{2}$ Marine Institute, Salmon Management Service Division, Newport, Co. Mayo, Ireland \\ ${ }^{3}$ Department of Biological Sciences, Hatherly Laboratories, University of Exeter, Exeter EX 4 4PS, UK
}

(Received 21 September 2001 ; revised 12 November 2001; accepted 12 November 2001)

S U M M A R Y

The aim of the present study was to compare the helminth infra and component communities of wild and stocked brown trout in Lough Feeagh, in the west of Ireland, and also to examine the establishment and development of helminth communities in stocked brown trout. Fish were sampled in May, August and November 1997 and 1998 and an additional sample of wild brown trout was examined in April 1997. In total 217 wild trout and 122 stocked trout were examined. The acanthocephalans Acanthocephalus clavula and Pomphorhynchus laevis were the first parasite species to infect stocked trout in May 1997. In May 1998 both acanthocephalan species along with the trout specialists Eubothrium crassum and Crepidostomum farionis were the first to infect trout. Mean species richness values for stocked trout increased from May to November, in 1997 and 1998. For wild trout, mean species richness values increased from April to November, in 1997 and decreased from May to November in 1998. The parasite communities of wild trout were richer than those of stocked trout in May of both years. In August the parasite communities recorded for wild and stocked trout were similar in terms of the number of species present but differed in terms of structure, and in November the parasite communities of stocked trout were richer than those of wild trout.

Key words: trout, infracommunity, component community, acanthocephalan.

\section{INTRODUCTION}

The parasite community ecology of resident brown trout (Salmo trutta L.) has received particular attention given their status as the dominant salmonid species in Europe (Bwathondi, 1984; Conneely \& McCarthy, 1988; Hartvigsen \& Halvorsen, 1993; Molloy, Holland \& Poole, 1995 ; Dorucu et al. 1995 ; Byrne et al. 2000). Kennedy \& Hartvigsen (2000) tested the hypothesis that the intestinal helminth communities in freshwater brown trout were dissimilar in composition and structure to those in European eels, by examining the component communities from 72 localities and the infracommunities from 34 localities in the British Isles and Norway. Composition of the helminth communities differed significantly between the 2 host groups. However, they identified a suite of 4 commonly occurring trout specialists which gave greater predictability to the trout parasite community composition.

Increasing levels of pollution, habitat decline, and overfishing have increased the importance of fish stocking as a fishery management option (Cragg-

* Corresponding author: Marine Institute, Salmon Management Services Division, Newport, Co. Mayo, Ireland. Tel: + 3531098 42316. Fax: +353098 43340. E-mail: cbyrne@anu.ie
Hine, 1992; Cowx, 1994). However, despite the relative abundance of parasite community studies on brown trout, no study has yet compared the parasite community structure, at any level, of wild and stocked brown trout in the same system. Poynton \& Bennett (1985) compared parasites of wild brown trout and stocked rainbow trout in a Hampshire river but this study was limited by small sample sizes and no parasite community parameters were examined. McGuigan \& Sommerville (1985) examined the effects of cage culture of rainbow trout on the parasite fauna of Lough Fad in western Scotland. However, this study was more concerned with the aquacultural implications of cage culture rather than parasite community ecology or interactions between wild and stocked trout.

The present study is the only such study to compare, in detail, the parasite communities of wild and stocked brown trout at the component and infracommunity levels in an oligotrophic lake, Lough Feeagh, over 2 successive years, 1997 and 1998. This was facilitated by the sea trout enhancement programme run by the Marine Institute, in which an average of 3500 pond reared brown trout were stocked into Lough Feeagh annually between 1996 and 1998. The establishment and development of the parasite communities in naïve stocked trout 
were examined at the infra and component community levels from the time of first entry of stocked fish into Lough Feeagh.

\section{MATERIALS AND METHODS}

Lough Feeagh is an oligotrophic freshwater lake of glacial origin located in the west of Ireland. It has an area of approximately 410 hectares, a maximum depth of $43 \mathrm{~m}$ and it lies at an altitude of $14 \mathrm{~m}$. The water in Lough Feeagh is soft and distinctly coloured, but transparency is only moderate. $\mathrm{pH}$ values range from $6 \cdot 3$ to $7 \cdot 0$ and conductivity values are around $80-90 \mu \mathrm{S} / \mathrm{m}$. Surface temperature values are generally within the range $3{ }^{\circ} \mathrm{C}$ to $20^{\circ} \mathrm{C}$. Lough Feeagh contains salmon, trout, eels and sticklebacks.

Coloured alphanumerically coded visible implant (V.I.) tags were used to identify fish stocked in Lough Feeagh in 1997 and 1998. Fish stocked in 1997 were tagged with green and red coloured tags and fish stocked in 1998 were tagged with orange coloured tags. Tags were injected dorsally, into the transparent tissue behind the eye of the fish, using a special applicator, according to the procedure described by Kincaid \& Calkins (1992). All fish were tagged on their right side. The code used on each V.I. tag is unique to individual fish and the colour referred to a batch of fish. Tagged fish also had their adipose fins removed to facilitate identification.

Beach Seine netting for wild and stocked fish was carried out on 7 occasions on Lough Feeagh between April 1997 and November 1998. Beach seine netting was carried out in accordance with the procedure described by Matthews et al. (1997). Once in the laboratory all fish were measured (fork length \pm $0 \cdot 1 \mathrm{~cm})$ and weighed $( \pm 0 \cdot 1 \mathrm{~g})$. Scales were removed from all wild fish for ageing, and all fish were subsequently frozen. Only 1-year-old wild trout $(1+)$, corresponding to the age of the stocked trout sample were considered for parasitological examination. Beach seine netting surveys carried out around the mouths of the rivers running into Lough Feeagh, suggest that large numbers of juvenile fish enter the lake during their first summer (i.e. as $0+$ trout) and over-winter in the lake (Matthews et al. 1997).

In 1997 samples of wild and stocked fish were collected in May, August and November and an additional sample of wild fish was collected in April. A similar sampling regime was adopted in 1998. However, due to unseasonable rainfall and the resulting high water level in Lough Feeagh, it was not possible to collect a sample of wild fish in April. Samples were taken in so far as possible to reflect seasonal differences in the fish and parasite populations and also as a function of fish availability. November was considered as the winter sample. August was considered as the summer sample, and
May was considered as the spring sample. Two control samples of stocked fish were also taken directly from the rearing ponds, 1 in $1997(n=72)$ and 1 in $1998(n=70)$, no parasite species were found in any of the control fish.

Fish were defrosted at room temperature and the general condition of the fish and any external lesions were noted. Viscera were removed and rinsed with $0.9 \%$ saline, which was kept and separately examined for parasites. The gills, liver, spleen, heart, gonads and swim bladder were all removed and examined for parasites. The body cavity was examined to detect any parasites which might be encysted there. Gonads were used to determine the sex of the fish. It was not possible to sex some juveniles as the gonads were not present. All parasites recovered were fixed in $10 \%$ formalin solution. Acanthocephalans were first placed in tap water for $24 \mathrm{~h}$ to evert the proboscis. At $24-48 \mathrm{~h}$ after fixation, parasites were washed in $70 \%$ ethanol and transferred to fresh $70 \%$ ethanol with $4 \%$ glycerol for long-term storage. Parasites were identified using the standard keys and, where necessary, they were cleared in lactophenol or stained with polyvinyl acetate and lignin pink.

The helminth community was examined at the infra and component community levels. The measures of component community richness used were percentage prevalence, mean abundance and mean intensity, all calculated according to Bush et al. (1997). The term component species, as defined by Bush et al. (1997), was used to refer to any parasite species which had a prevalence value of $10 \%$ or more. Similarities in the parasite communities of wild and stocked fish were calculated using Sorenson's index of similarity at the component community level. The measures of infracommunity richness used were the mean species richness, mean number of individuals and the Brillouin's index of diversity which was calculated for intestinal worms only. The Shannon diversity index was also calculated. All indices used were calculated according to Magurran (1988). One-way analysis of variance was used to compare the abundance values of the 4 most common species (E. crassum, C.farionis, P. laevis, $A$. clavula) between the April 1997 wild trout sample and the remaining wild trout samples. Three-way analysis of variance (ANOVA) was used to examine the relationships between fish status (whether fish were wild or stocked), the month (May, August and November) and year of capture and the abundance of the four most prevalent species. Three-way analysis of variance (ANOVA) was also used to examine the relationships between fish status, the month and year of capture and each of 3 dependent variables, the species richness, the number of individuals, and the Brillouin's index of diversity. In all cases nonnormal data were transformed using log transformations, prior to any statistical analysis being undertaken. 
RESULTS

Data summarizing the parasite component communities of wild and stocked trout in each sample month in 1997 and 1998 (April, May, August, November) are presented in Tables 1-4, and data summarizing the parasite component communities of the total wild and stocked trout samples are presented in Table 5. The stocked trout examined in April 1997 and 1998 represent control samples; fish were sampled directly from rearing ponds prior to being released.

\section{Component community structure}

April

No parasites were found in trout stocked in April 1997 or trout stocked in 1998 (Table 1). This confirms that trout being stocked into Lough Feeagh were initially metazoan parasite-free and that any parasites subsequently found in stocked trout were acquired from that lake. It was not possible to compare the wild $1+$ trout sample from April 1997 to any corresponding wild trout sample (as no wild $1+$ trout were examined in 1998). However, when the wild $1+$ trout sample from April 1997 was compared to the total wild $1+$ trout sample (Table 5) $C$. farionis had the highest mean abundance and mean intensity values in both samples. $P$. laevis had the highest prevalence in the total sample and the nematode Rhabdochona sp. had the highest prevalence in the April 1997 sample. One-way analysis of variance (ANOVA) showed significant differences in the abundance of $E$. crassum $(\mathrm{F}$ ratio $=9.57$; D.F. $=$ $1,215 ; P \leqslant 0 \cdot 002), P$. laevis (F ratio $=7 \cdot 12 ;$ D.F. $=$ $1,215 ; P \leqslant 0 \cdot 008)$ and $A$. clavula $(\mathrm{F}$ ratio $=7 \cdot 35 ;$ D.F. $=1,215 ; P \leqslant 0.007)$ between the April 1997 wild $1+$ trout sample and the remaining trout samples.

\section{May}

Only 2 parasite species, the acanthocephalans $P$. laevis and $A$. clavula were recorded in stocked trout in May 1997 (Table 2). The same 2 acanthocephalan species along with $C$. farionis and E. crassum were recorded in stocked trout in May 1998. All species recorded in stocked trout, with the exception of $E$. crassum in 1998 were component species. A. clavula had the highest prevalence, mean abundance and mean intensity values in stocked trout in 1997 and 1998. In wild trout the highest component community parameters were recorded for $P$. laevis in 1997 whereas in 1998 P. laevis had the highest prevalence, but $C$. farionis had the highest mean abundance and mean intensity values. With the exception of the prevalence and mean abundance values for $P$. laevis, all other component community parameters were higher for the 4 most common species (E. crassum, C.farionis, P. laevis, A. clavula) in 1998.

\section{August}

The parasite component communities recorded for stocked trout in August of both years contained more species (and were more comparable to the parasite communities recorded for wild trout in August) than the component communities recorded for stocked trout in May. Eight parasite species were recorded in stocked trout in August 1997 and 9 were recorded in 1998 , in both years all species recorded were component species (Table 3). Nine parasite species were recorded in wild trout in 1997 and 8 species were recorded in 1998, of these only 5 were component species in 1997 and all were component species in 1998. In 1997 E. crassum had the highest prevalence and Diphyllobothrium ditremum had the highest mean abundance and mean intensity values in stocked trout and $P$. laevis had the highest prevalence, mean abundance and mean intensity values in wild trout. All component community parameters recorded for $A$. clavula were higher than those recorded for $P$. laevis in stocked trout in 1997 and 1998. In contrast all component community parameters recorded for $P$. laevis in wild trout were higher than those recorded for A. clavula in 1998, and in 1997 prevalence and mean abundance values were higher for $P$. laevis.

\section{November}

The same 9 parasite species were recorded in stocked trout in November 1997 and 1998 and in wild trout in 1998. Seven parasite species were recorded in wild trout in 1997. Five component species were recorded in wild trout in 1997 and 7 component species were recorded in wild trout in 1998 . E. crassum had the highest component community parameters in 1997 whereas in $1998 P$. laevis had the highest prevalence value, $A$. clavula had the highest mean abundance value and $E$. crassum had the highest mean intensity value. Four component species were recorded in stocked trout in 1997, compared to 1998 when all species recorded were component species (Table 4). All of the component community parameters recorded for P. laevis were higher than those recorded for A. clavula in stocked trout in 1997 and 1998 and in wild trout in 1997. The highest component community values were recorded for $P$. laevis in stocked trout in 1997, whereas in 1998 E. crassum had the highest prevalence value and $D$. ditremum had the highest mean abundance and mean intensity values.

\section{Statistical analysis}

Three-way analysis of variance showed significant differences in the abundance of $E$. crassum between wild and stocked trout $(\mathrm{F}$ ratio $=28.83$; D.F. $=$ $1,305 ; P \leqslant 0 \cdot 0001)$ and between months $(\mathrm{F}$ ratio $=$ 
Table 1. Helminth component community data for wild and stocked trout from Lough Feeagh in April 1997 and 1998

(IN, intestine, V, viscera; S, stomach; SB, swimbladder; G, gills, \% prevalence; A, mean abundance (s.D.); I, mean intensity (s.D.).)

\begin{tabular}{|c|c|c|c|c|c|c|c|c|c|c|c|c|c|}
\hline \multirow[b]{2}{*}{ Parasites } & \multirow[b]{2}{*}{ Site } & \multicolumn{3}{|c|}{ April 97 Wild $(n=29)$} & \multicolumn{3}{|c|}{ April 97 Stocked $(n=70)$} & \multicolumn{3}{|c|}{ April 98 Wild } & \multicolumn{3}{|c|}{ April 98 Stocked $(n=70)$} \\
\hline & & $\%$ & $\mathrm{~A}$ & I & $\%$ & A & I & $\%$ & A & I & $\%$ & A & I \\
\hline Eubothrium crassum & IN & 0 & 0 & 0 & 0 & 0 & 0 & - & - & - & 0 & 0 & 0 \\
\hline Crepidostomum farionis & IN & $48 \cdot 3$ & $2 \cdot 7(3 \cdot 8)$ & $5 \cdot 6(3 \cdot 7)$ & 0 & 0 & 0 & - & - & - & 0 & 0 & 0 \\
\hline Pomphorhynchus laevis & IN & $51 \cdot 7$ & $2 \cdot 6(5 \cdot 1)$ & $5 \cdot 1(6 \cdot 3)$ & 0 & 0 & 0 & - & - & - & 0 & 0 & 0 \\
\hline Acanthocephalus clavula & IN & 0 & 0 & 0 & 0 & 0 & 0 & - & - & - & 0 & 0 & 0 \\
\hline Rhabdochona sp. & IN & $55 \cdot 2$ & $2 \cdot 5(3 \cdot 4)$ & $4 \cdot 4(3 \cdot 4)$ & 0 & 0 & 0 & - & - & - & 0 & 0 & 0 \\
\hline Diphyllobothrium ditremum & $\mathrm{V}$ & $3 \cdot 5$ & $0 \cdot 3(0 \cdot 2)$ & $1(0)$ & 0 & 0 & 0 & - & - & - & 0 & 0 & 0 \\
\hline Cystidicoloides tenuissima & $\mathrm{S}$ & 0 & 0 & 0 & 0 & 0 & 0 & - & - & - & 0 & 0 & 0 \\
\hline Cystidicola farionis & $\mathrm{SB}$ & 0 & 0 & 0 & 0 & 0 & 0 & - & - & - & 0 & 0 & 0 \\
\hline Discocotyle sagittata & G & 0 & 0 & 0 & 0 & 0 & 0 & - & - & - & 0 & 0 & 0 \\
\hline Salmincola salmoneus & $\mathrm{G}$ & $3 \cdot 5$ & $0 \cdot 3(0 \cdot 2)$ & $1(0)$ & 0 & 0 & 0 & - & - & - & 0 & 0 & 0 \\
\hline
\end{tabular}

Table 2. Helminth component community data for wild and stocked trout from Lough Feeagh in May 1997 and 1998

(IN, intestine, V, viscera; S, stomach; SB, swimbladder; G, gills, \% prevalence; A, mean abundance (s.D.); I, mean intensity (s.D.).)

\begin{tabular}{|c|c|c|c|c|c|c|c|c|c|c|c|c|c|}
\hline \multirow[b]{2}{*}{ Parasites } & \multirow[b]{2}{*}{ Site } & \multicolumn{3}{|c|}{ May 97 Wild $(n=32)$} & \multicolumn{3}{|c|}{ May 97 Stocked $(n=21)$} & \multicolumn{3}{|c|}{ May 98 Wild $(n=32)$} & \multicolumn{3}{|c|}{ May 98 Stocked $(n=26)$} \\
\hline & & $\%$ & A & I & $\%$ & A & I & $\%$ & A & I & $\%$ & $\mathrm{~A}$ & I \\
\hline Eubothrium crassum & IN & $3 \cdot 1$ & $0 \cdot 03(0 \cdot 2)$ & $1(0)$ & 0 & 0 & 0 & $31 \cdot 3$ & $2 \cdot 1(4 \cdot 9)$ & $6 \cdot 7(7)$ & $7 \cdot 7$ & $0 \cdot 1(0 \cdot 4)$ & $1 \cdot 5(0 \cdot 7)$ \\
\hline Crepidostomum farionis & IN & $21 \cdot 9$ & $1.6(3.9)$ & $7 \cdot 4(5 \cdot 2)$ & 0 & & 0 & $78 \cdot 1$ & $30 \cdot 6(34 \cdot 5)$ & $39 \cdot 2(34 \cdot 5)$ & $15 \cdot 4$ & $1(4)$ & $6 \cdot 8(8 \cdot 9)$ \\
\hline Pomphorhynchus laevis & IN & $96 \cdot 9$ & $9 \cdot 4(6 \cdot 7)$ & $9 \cdot 7(6 \cdot 6)$ & $19 \cdot 1$ & $0 \cdot 8(2 \cdot 3)$ & $4 \cdot 3(4)$ & $84 \cdot 4$ & $8 \cdot 7(15 \cdot 4)$ & $10 \cdot 3(16 \cdot 3)$ & $46 \cdot 2$ & $1 \cdot 4(2 \cdot 6)$ & $3 \cdot 1(3 \cdot 2)$ \\
\hline Acanthocephalus clavula & IN & $18 \cdot 8$ & $0 \cdot 4(1 \cdot 2)$ & $2 \cdot 3(1 \cdot 8)$ & $28 \cdot 6$ & $1 \cdot 7(6 \cdot 1)$ & $5 \cdot 8(10 \cdot 9)$ & 50 & $8 \cdot 8(20 \cdot 4)$ & $17 \cdot 5(26 \cdot 4)$ & $57 \cdot 7$ & $4 \cdot 1(6)$ & $7 \cdot 1(6 \cdot 5)$ \\
\hline Rhabdochona sp. & IN & 0 & 0 & 0 & 0 & 0 & 0 & $9 \cdot 4$ & $0 \cdot 2(0 \cdot 8)$ & $2 \cdot 3(1 \cdot 5)$ & 0 & 0 & 0 \\
\hline Diphyllobothrium ditremum & $\mathrm{V}$ & $3 \cdot 1$ & $3(0 \cdot 2)$ & $1(0)$ & 0 & 0 & 0 & $15 \cdot 6$ & $0 \cdot 4(1 \cdot 2)$ & $2 \cdot 4(2 \cdot 2)$ & 0 & 0 & 0 \\
\hline Cystidicoloides tenuissima & $\mathrm{S}$ & 0 & 0 & 0 & 0 & 0 & 0 & 0 & 0 & 0 & 0 & 0 & 0 \\
\hline Cystidicola farionis & $\mathrm{SB}$ & $3 \cdot 1$ & $0 \cdot 03(0 \cdot 2)$ & $1(0)$ & 0 & 0 & 0 & $9 \cdot 4$ & $1 \cdot 2(5 \cdot 5)$ & $12 \cdot 7(25 \cdot 9)$ & 0 & 0 & 0 \\
\hline Discocotyle sagittata & G & $3 \cdot 1$ & $0 \cdot 1(0 \cdot 5)$ & $3(0)$ & 0 & 0 & 0 & $6 \cdot 3$ & $0 \cdot 1(0 \cdot 5)$ & $2(0)$ & 0 & 0 & 0 \\
\hline Salmincola salmoneus & G & 0 & 0 & 0 & 0 & 0 & 0 & $31 \cdot 3$ & $0 \cdot 6(1 \cdot 2)$ & $1 \cdot 8(1 \cdot 6)$ & 0 & 0 & 0 \\
\hline
\end{tabular}


Table 3. Helminth component community data for wild and stocked trout from Lough Feeagh in August 1997 and 1998

(IN, intestine, V, viscera; S, stomach; SB, swimbladder; G, gills, \% prevalence; A, mean abundance (s.D.); I, mean intensity (s.D.).)

\begin{tabular}{|c|c|c|c|c|c|c|c|c|c|c|c|c|c|}
\hline \multirow[b]{2}{*}{ Parasites } & \multirow[b]{2}{*}{ Site } & \multicolumn{3}{|c|}{ August 97 Wild $(n=47)$} & \multicolumn{3}{|c|}{ August 97 Stocked $(n=15)$} & \multicolumn{3}{|c|}{ August 98 Wild $(n=31)$} & \multicolumn{3}{|c|}{ August 98 Stocked $(n=10)$} \\
\hline & & $\%$ & A & I & $\%$ & A & I & $\%$ & A & I & $\%$ & $\mathrm{~A}$ & I \\
\hline Eubothrium crassum & IN & $23 \cdot 4$ & $2 \cdot 1(5 \cdot 3)$ & $3 \cdot 1(7 \cdot 6)$ & $86 \cdot 7$ & $12 \cdot 6(23 \cdot 4)$ & $14 \cdot 5(24 \cdot 7)$ & $22 \cdot 6$ & $2 \cdot 4(6 \cdot 3)$ & $10 \cdot 6(9 \cdot 8)$ & 90 & $51 \cdot 3(86 \cdot 6)$ & $57(89 \cdot 8)$ \\
\hline Crepidostomum farionis & IN & $31 \cdot 9$ & $2 \cdot 5(7)$ & $7 \cdot 9(10 \cdot 8)$ & 20 & $1 \cdot 1(2 \cdot 8)$ & $5 \cdot 3(4 \cdot 5)$ & $35 \cdot 5$ & $2 \cdot 9(6 \cdot 3)$ & $8 \cdot 3(8 \cdot 4)$ & 50 & $1 \cdot 6(2 \cdot 3)$ & $3 \cdot 2(2 \cdot 3)$ \\
\hline Pomphorhynchus laevis & IN & $72 \cdot 3$ & $5 \cdot 2(7 \cdot 3)$ & $7 \cdot 1(7 \cdot 7)$ & 20 & $0 \cdot 3(0 \cdot 6)$ & $1 \cdot 3(0 \cdot 6)$ & $45 \cdot 2$ & $3 \cdot 7(8 \cdot 8)$ & $8 \cdot 1(11 \cdot 9)$ & 20 & $0 \cdot 5(1 \cdot 3)$ & $2 \cdot 5(2 \cdot 1)$ \\
\hline Acanthocephalus clavula & IN & $25 \cdot 5$ & $3 \cdot 2(11 \cdot 6)$ & $12 \cdot 6(20 \cdot 9)$ & 40 & $7 \cdot 6(21 \cdot 6)$ & $19(32 \cdot 4)$ & $32 \cdot 3$ & $4 \cdot 7(14 \cdot 9)$ & $14 \cdot 6(24)$ & 30 & $7 \cdot 3(20)$ & $24 \cdot 3(34 \cdot 4)$ \\
\hline Rhabdochona sp. & IN & $12 \cdot 8$ & $0 \cdot 3(1)$ & $2 \cdot 5(1 \cdot 8)$ & $13 \cdot 3$ & $0 \cdot 3(0 \cdot 7)$ & $2(0)$ & $25 \cdot 8$ & $0 \cdot 8(1 \cdot 6)$ & $3(1 \cdot 7)$ & 10 & $0 \cdot 2(0 \cdot 6)$ & $2(0)$ \\
\hline Diphyllobothrium ditremum & $\mathrm{V}$ & $8 \cdot 5$ & $1(4 \cdot 3)$ & $11 \cdot 3(11 \cdot 6)$ & $33 \cdot 3$ & $13 \cdot 3(49 \cdot 2)$ & $40(84 \cdot 4)$ & $19 \cdot 4$ & $1 \cdot 3(3 \cdot 6)$ & $6 \cdot 7(5 \cdot 8)$ & 50 & $23 \cdot 7(48 \cdot 8)$ & $47 \cdot 4(62 \cdot 8)$ \\
\hline Cystidicoloides tenuissima & $\mathrm{S}$ & $6 \cdot 4$ & $0 \cdot 2(1)$ & $3 \cdot 7(2 \cdot 1)$ & 0 & 0 & 0 & 0 & 0 & 0 & 10 & $0 \cdot 1(0 \cdot 3)$ & $1(0)$ \\
\hline Cystidicola farionis & $\mathrm{SB}$ & 0 & 0 & 0 & $13 \cdot 3$ & $0 \cdot 1(0 \cdot 4)$ & $1(0)$ & $6 \cdot 5$ & $0 \cdot 2(0 \cdot 8)$ & $3(0)$ & 0 & 0 & 0 \\
\hline Discocotyle sagittata & $\mathrm{G}$ & $2 \cdot 1$ & $0 \cdot 04(0 \cdot 3)$ & $2(0)$ & 0 & 0 & 0 & 29 & $0 \cdot 5(1 \cdot 2)$ & $1 \cdot 8(1 \cdot 6)$ & 50 & $1(1 \cdot 3)$ & $2(1 \cdot 2)$ \\
\hline Salmincola salmoneus & G & $4 \cdot 3$ & $0 \cdot 6(0 \cdot 3)$ & $1.5(0 \cdot 7)$ & $13 \cdot 3$ & $0 \cdot 1(0 \cdot 4)$ & $1(0)$ & $9 \cdot 7$ & $0 \cdot 1(0 \cdot 3)$ & $1(0)$ & 10 & $0 \cdot 1(0 \cdot 3)$ & $0 \cdot 1(0 \cdot 3)$ \\
\hline
\end{tabular}

Table 4. Helminth component community data for wild and stocked trout from Lough Feeagh in November 1997 and 1998

(IN, intestine, V, viscera; S, stomach; SB, swimbladder; G, gills, \% prevalence; A, mean abundance (S.D.); I, mean intensity (s.D.).)

\begin{tabular}{|c|c|c|c|c|c|c|c|c|c|c|c|c|c|}
\hline \multirow[b]{2}{*}{ Parasites } & \multirow[b]{2}{*}{ Site } & \multicolumn{3}{|c|}{ November 97 Wild $(n=14)$} & \multicolumn{3}{|c|}{ November 97 Stocked $(n=23)$} & \multicolumn{3}{|c|}{ November 98 Wild $(n=31)$} & \multicolumn{3}{|c|}{ November 98 Stocked $(n=25)$} \\
\hline & & $\%$ & A & I & $\%$ & A & I & $\%$ & $\mathrm{~A}$ & I & $\%$ & $\mathrm{~A}$ & I \\
\hline Eubothrium crassum & IN & $78 \cdot 6$ & $6 \cdot 4(7 \cdot 7)$ & $8 \cdot 2(7 \cdot 9)$ & 96 & $8 \cdot 4(6 \cdot 6)$ & $8 \cdot 8(6 \cdot 5)$ & $22 \cdot 6$ & $2 \cdot 4(6 \cdot 3)$ & $10 \cdot 6(9 \cdot 8)$ & 84 & $4 \cdot 7(5 \cdot 1)$ & $5 \cdot 6(5 \cdot 1)$ \\
\hline Crepidostomum farionis & IN & $7 \cdot 1$ & $0 \cdot 1(0 \cdot 3)$ & $1(1)$ & 8 & $0 \cdot 1(0 \cdot 4)$ & $1(1 \cdot 5)$ & $35 \cdot 5$ & $2 \cdot 9(6 \cdot 3)$ & $8 \cdot 3(8 \cdot 4)$ & 52 & $7 \cdot 4(19)$ & $14 \cdot 2(24 \cdot 8)$ \\
\hline Pomphorhynchus laevis & IN & 50 & $3 \cdot 9(5 \cdot 8)$ & $7 \cdot 9(6 \cdot 1)$ & 100 & $13 \cdot 9(13 \cdot 3)$ & $13 \cdot 9(13 \cdot 3)$ & $45 \cdot 2$ & $3 \cdot 7(8 \cdot 8)$ & $8 \cdot 1(11 \cdot 9)$ & 68 & $5(8 \cdot 8)$ & $7 \cdot 4(9 \cdot 9)$ \\
\hline Acanthocephalus clavula & IN & $14 \cdot 3$ & $0 \cdot 2(0 \cdot 4)$ & $1 \cdot 5(0 \cdot 7)$ & 20 & $1 \cdot 4(5)$ & $6 \cdot 8(10 \cdot 2)$ & $32 \cdot 3$ & $4 \cdot 7(14 \cdot 9)$ & $14 \cdot 6(24)$ & 52 & $3 \cdot 4(7 \cdot 5)$ & $6 \cdot 5(9 \cdot 5)$ \\
\hline Rhabdochona sp. & IN & 0 & 0 & 0 & 4 & $0 \cdot 04(0 \cdot 02)$ & $1(0)$ & $25 \cdot 8$ & $0 \cdot 8(1 \cdot 6)$ & $3(1 \cdot 7)$ & 48 & $2(3 \cdot 3)$ & $4 \cdot 3(3 \cdot 57)$ \\
\hline Diphyllobothrium ditremum & $\mathrm{V}$ & $64 \cdot 3$ & $2 \cdot 4(4 \cdot 3)$ & $3 \cdot 7(5)$ & 64 & $2 \cdot 5(3 \cdot 8)$ & $3 \cdot 9(4 \cdot 2)$ & $19 \cdot 4$ & $1 \cdot 3(3 \cdot 6)$ & $6 \cdot 7(5 \cdot 8)$ & 64 & $9 \cdot 2(18 \cdot 8)$ & $14 \cdot 4(22 \cdot 1)$ \\
\hline Cystidicoloides tenuissima & $\mathrm{S}$ & 0 & 0 & 0 & 0 & 0 & 0 & 0 & 0 & 0 & 0 & 0 & 0 \\
\hline Cystidicola farionis & SB & 0 & 0 & 0 & 8 & $0 \cdot 7(2 \cdot 5)$ & $9(0)$ & $6 \cdot 5$ & $0 \cdot 2(0 \cdot 8)$ & $3(0)$ & 20 & $1 \cdot 4(5 \cdot 2)$ & $6 \cdot 8(10 \cdot 8)$ \\
\hline Discocotyle sagittata & $\mathrm{G}$ & $21 \cdot 4$ & $0 \cdot 3(0 \cdot 6)$ & $1 \cdot 3(0 \cdot 6)$ & 4 & $0 \cdot 04(0 \cdot 2)$ & $1(0)$ & 29 & $0 \cdot 5(1 \cdot 2)$ & $1 \cdot 8(1 \cdot 6)$ & 44 & $1(1 \cdot 7)$ & $2 \cdot 2(1 \cdot 9)$ \\
\hline Salmincola salmoneus & G & $7 \cdot 1$ & $0 \cdot 1(0 \cdot 3)$ & $1(0)$ & 8 & $0 \cdot 1(0 \cdot 4)$ & $1 \cdot 5(0 \cdot 7)$ & $9 \cdot 7$ & $0 \cdot 1(0 \cdot 3)$ & $1(0)$ & 20 & $0 \cdot 3(0 \cdot 61)$ & $1 \cdot 4(0 \cdot 6)$ \\
\hline
\end{tabular}


Table 5. Total helminth component community data for wild and stocked trout samples from Lough Feeagh in 1997 and 1998

(IN, intestine, V, viscera; S, stomach; SB, swimbladder; G, gills, \% prevalence; A, mean abundance (s.D.); I, mean intensity (S.D.).)

\begin{tabular}{|c|c|c|c|c|c|c|c|}
\hline \multirow[b]{2}{*}{ Parasites } & \multirow[b]{2}{*}{ Site } & \multicolumn{3}{|c|}{ Total Wild $(n=217)$} & \multicolumn{3}{|c|}{ Total Stocked $(n=122)$} \\
\hline & & $\%$ & $\mathrm{~A}$ & $\mathrm{I}$ & $\%$ & A & I \\
\hline Eubothrium crassum & IN & $26 \cdot 3$ & $2 \cdot 2(5 \cdot 9)$ & $8 \cdot 1(8 \cdot 9)$ & $56 \cdot 6$ & $8 \cdot 5(28 \cdot 6)$ & $15(36 \cdot 9)$ \\
\hline Crepidostomum farionis & IN & $40 \cdot 1$ & $6 \cdot 4(17 \cdot 2)$ & $15(23 \cdot 8)$ & $22 \cdot 1$ & $2(9 \cdot 1)$ & $9 \cdot 1(17 \cdot 9)$ \\
\hline Pomphorhynchus laevis & IN & $70 \cdot 4$ & $5 \cdot 4(8 \cdot 7)$ & $7 \cdot 7(9 \cdot 5)$ & $51 \cdot 6$ & $4 \cdot 4(8 \cdot 9)$ & $8 \cdot 5(10 \cdot 9)$ \\
\hline Acanthocephalus clavula & IN & $25 \cdot 8$ & $3(11 \cdot 4)$ & $11 \cdot 7(20 \cdot 2)$ & $39 \cdot 3$ & $3 \cdot 7(10 \cdot 9)$ & $9 \cdot 3(15 \cdot 9)$ \\
\hline Rhabdochona sp. & IN & $14 \cdot 7$ & $0 \cdot 5(1 \cdot 7)$ & $3 \cdot 5(2 \cdot 8)$ & $13 \cdot 1$ & $0 \cdot 5(1 \cdot 7)$ & $3 \cdot 4(3 \cdot 3)$ \\
\hline Diphyllobothrium ditremum & $\mathrm{V}$ & $15 \cdot 2$ & $0 \cdot 9(3 \cdot 3)$ & $5 \cdot 7(6 \cdot 6)$ & $34 \cdot 4$ & $6(24 \cdot 1)$ & $17 \cdot 4(38 \cdot 9)$ \\
\hline Cystidicoloides tenuissima & $\mathrm{S}$ & $4 \cdot 1$ & $0 \cdot 6(4 \cdot 5)$ & $14 \cdot 1(18 \cdot 2)$ & $0 \cdot 8$ & $0 \cdot 01(0 \cdot 1)$ & $1(0)$ \\
\hline Cystidicola farionis & SB & $3 \cdot 2$ & $0 \cdot 2(2 \cdot 2)$ & $7 \cdot 5(11 \cdot 6)$ & $7 \cdot 4$ & $0 \cdot 4(2 \cdot 6)$ & $6(8 \cdot 2)$ \\
\hline Discocotyle sagittata & G & $11 \cdot 5$ & $0 \cdot 2(0 \cdot 7)$ & $1 \cdot 9(1 \cdot 3)$ & $13 \cdot 9$ & $0 \cdot 3(0 \cdot 9)$ & $2 \cdot 1(1 \cdot 7)$ \\
\hline Salmincola salmoneus & $\mathrm{G}$ & $10 \cdot 6$ & $0 \cdot 2(0 \cdot 6)$ & $1 \cdot 6(1 \cdot 2)$ & $8 \cdot 2$ & $0 \cdot 1(0 \cdot 4)$ & $1 \cdot 3(0 \cdot 5)$ \\
\hline
\end{tabular}

Table 6. Sorenson's index of similarity between wild and stocked trout in May, August and November of 1997 and 1998

\begin{tabular}{lllll}
\hline \hline & & \multicolumn{3}{l}{ Wild } \\
& 1997 & May & August & November \\
\hline \multirow{3}{*}{ Stocked } & May & $0 \cdot 15$ & $0 \cdot 14$ & $0 \cdot 17$ \\
& August & $0 \cdot 08$ & $0 \cdot 47$ & $0 \cdot 37$ \\
& November & $0 \cdot 61$ & $0 \cdot 63$ & $0 \cdot 42$ \\
& & & Wild & \\
\hline \multirow{3}{*}{ Stocked } & 1998 & May & August & November \\
& May & $0 \cdot 19$ & $0 \cdot 34$ & $0 \cdot 50$ \\
& August & $0 \cdot 14$ & $0 \cdot 42$ & $0 \cdot 32$ \\
& November & $0 \cdot 41$ & $0 \cdot 60$ & $0 \cdot 66$ \\
\hline \hline
\end{tabular}

$36 \cdot 18$; D.F. $=2,305 ; P \leqslant 0 \cdot 001)$ but not between years. Significant differences in the abundance of $C$. farionis existed between wild and stocked trout $(\mathrm{F}$ ratio $=14.41 ;$ D.F. $=1,305 ; P \leqslant 0.0002)$, between months $(\mathrm{F}$ ratio $=4.59 ;$ D.F. $=2,305 ; \quad P=0.01)$ and between years $(\mathrm{F}$ ratio $=34.61 ;$ D.F. $=1,305$; $P \leqslant 0 \cdot 0001)$.

For $P$. laevis significant differences in abundance existed between wild and stocked trout $(\mathrm{F}$ ratio $=$ $16 \cdot 12$; D.F. $=1,305 ; P \leqslant 0.0001)$, between months $(\mathrm{F}$ ratio $=7.84 ;$ D.F. $=2,305 ; P \leqslant 0.0005)$ and between years $(\mathrm{F}$ ratio $=10.9 ;$ D.F. $=1,305 ; P \leqslant$ $0.001)$. For $A$. clavula significant differences in the abundance existed between years ( $\mathrm{F}$ ratio $=14.0$; D.F. $=1,305 ; P \leqslant 0.0002)$ but not between months or between wild and stocked trout.

Summary data on the parasite communities of wild and stocked trout in Lough Feeagh are presented in Table 5. Ten parasite species were identified in wild and stocked brown trout. D. ditremum was allogenic and the remaining 9 species were autogenic. D. ditremum was also the only larval species present. $P$. laevis had the highest overall prevalence value in wild trout and $C$. farionis had the highest mean abundance and mean intensity values. $E$. crassum had the highest overall prevalence and mean abundance values in stocked trout and $D$. ditremum had the highest mean intensity value. Eight component species were recorded in wild trout, and 7 were recorded in stocked trout. The nematodes Cystidicola farionis, and Cystidicoloides tenuissima were noncomponent species in wild and stocked trout and the copepod Salmincola salmoneus was also a noncomponent species in stocked trout. Stocked trout had the highest prevalence values for $E$. crassum, D. ditremum, A. clavula, Cystidicola farionis and Discocotyle sagittata, and wild trout had the highest prevalence values for the remaining 5 species. At the component community level Sorenson's index was used to examine the parasite community similarity between wild and stocked trout for each month in 1997 and 1998 (Table 6). In 1997 the highest level of community similarity recorded between wild and stocked trout occurred in August; however, the highest overall level of community similarity occurred between wild trout in August and stocked 


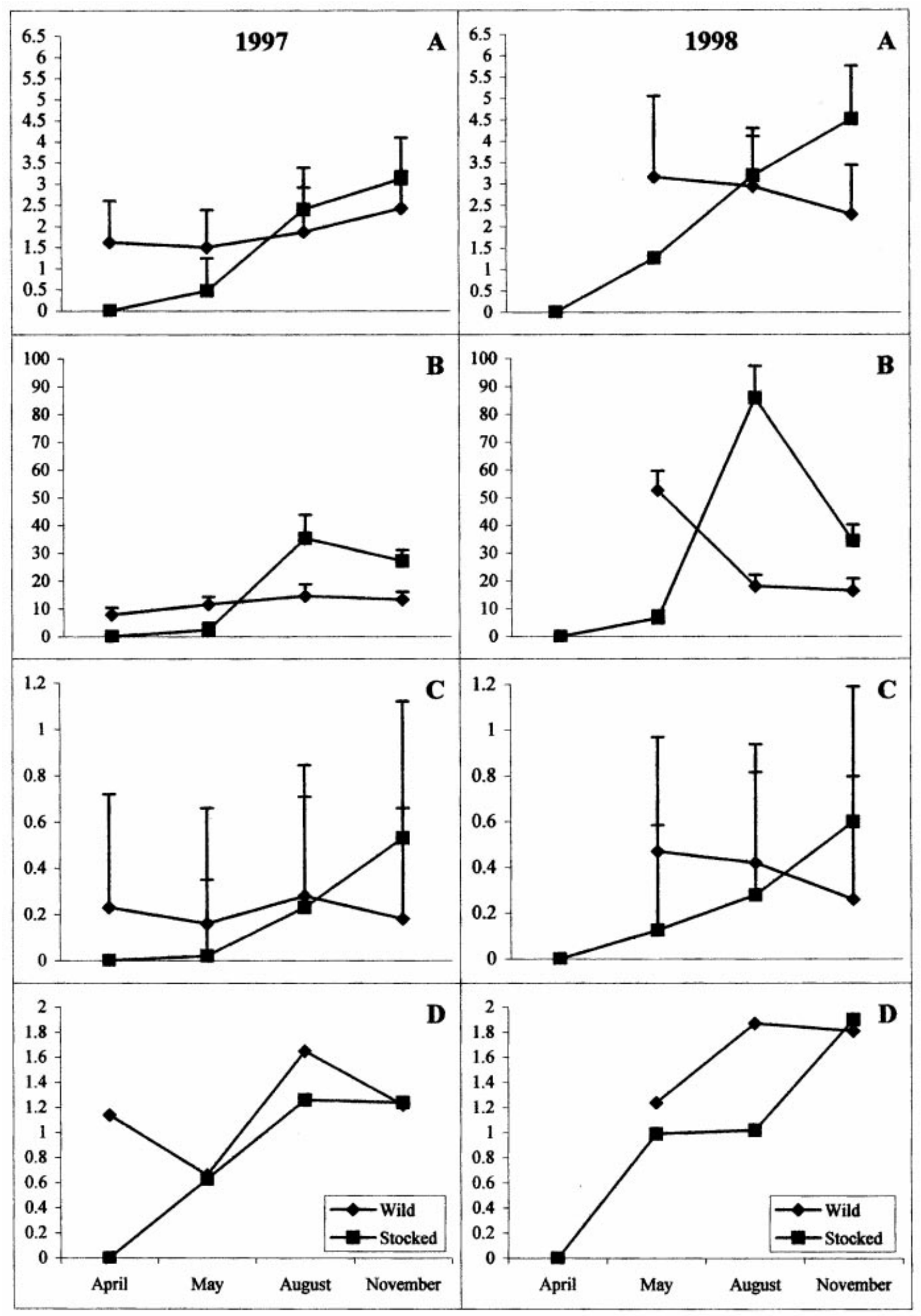

Fig. 1. Infracommunity parameters for wild and stocked fish from Lough Feeagh in 1997 and 1998. (A) Mean species richness; (B) mean number of individuals; (C) Brillouin's index (intestinal worms only); (D) Shannon diversity index). Standard error (s.E.) bars are shown where necessary and, for purposes of clarity, only positive standard error bars have been shown.

trout in November. In 1998 the level of community similarity between wild and stocked trout increased from May to a peak in November. The Sorenson's index value recorded in November was the highest parasite community similarity value recorded in 1998. 


\section{Infracommunity structure}

Nine wild trout and 16 stocked trout (excluding the control samples) harboured no metazoan parasites. Values for the mean species richness, mean number of individuals, Brillouin's index of diversity (intestinal worms only) and the Shannon diversity index are presented in Fig. 1. In 1997 and 1998, values for the mean species richness and the mean number of individuals for stocked trout increased from zero in April, when fish were first put into Lough Feeagh, to values comparable with the corresponding wild trout samples in August and to values in excess of those recorded for wild trout in November. A similar situation occurred for the Brillouin's index of diversity values recorded for stocked trout in 1998; however, in 1997 values for the Brillouin's index of diversity for wild trout were higher in all months than for the corresponding stocked trout sample (Fig. 1). Values for the Shannon diversity index for stocked trout also increased from zero in April; however, in 1997 values peaked in August and decreased in November, whereas in 1998 values peaked in November. In wild trout, values for the Shannon diversity index peaked in August 1997 and 1998. In all cases with the exceptions of the mean species richness value for wild trout in November 1997 and the Shannon diversity index value for stocked trout in August 1997 infracommunity parameters were higher in 1998.

\section{Statistical analysis}

In all analyses, the April samples for wild and stocked trout have been excluded, as only 1 wild trout sample was taken and the stocked trout were taken from rearing ponds as a control sample.

\section{Species richness}

No significant differences in species richness existed between stocked and wild fish. The interactions between month and year and year and fish status (wild or stocked) were also non-significant. However there were significant differences in the species richness recorded between months $(\mathrm{F}$ ratio $=46 \cdot 38$; D.F. $=2,298 ; P \leqslant 0.0001)$ and between years ( $\mathrm{F}$ ratio $=46 \cdot 25$; D.F. $=1,298 ; P \leqslant 0 \cdot 0001)$. The interactions between month and fish status $(\mathrm{F}$ ratio $=44.54$; D.F. $=2,298 ; P \leqslant 0.0001)$ and between month year and fish status $(\mathrm{F}$ ratio $=7.72 ;$ D.F. $=2,298 ; P \leqslant 0.0005)$ were also significant.

\section{Number of individuals}

No significant differences in the number of individuals were recorded between years. The interactions between fish status and year and between fish status, month and year were also non-significant. Signifi- cant differences in the number of individuals were recorded between fish status $(\mathrm{F}$ ratio $=13 \cdot 54$; D.F. $=$ $1,326 ; P \leqslant 0.0003)$ and between months $(\mathrm{F}$ ratio $=$ $11.02 ;$ D.F. $=3,326 ; P \leqslant 0.0001)$. The interactions between fish status and month $(\mathrm{F}$ ratio $=57 \cdot 7$; D.F. $=2,236 ; P \leqslant 0.0001)$ and between month and year $(\mathrm{F}$ ratio $=9.48 ;$ D.F. $=2,326 ; P \leqslant 0.0001)$ were also significant.

\section{Brillouin's index}

No significant differences in the Brillouin's index of diversity existed between stocked and wild fish. The interactions between year and month and year and fish status were also non-significant. Significant differences in the Brillouin's index of diversity existed between years $(\mathrm{F}$ ratio $=20 \cdot 7$; D.F. $=1,294$; $P \leqslant 0.0001)$ and months (F ratio $=41.81$; D.F. $=$ $2,294 ; P \leqslant 0 \cdot 0001)$. However, the interactions between month and fish status $(\mathrm{F}$ ratio $=29 \cdot 88$; D.F. $=$ $2,294 ; P \leqslant 0 \cdot 0001)$ and between year, month and fish status $(\mathrm{F}$ ratio $=3.39$; D.F. $=2,294 ; P \leqslant 0.03)$ were significant.

\section{DISCUSSION}

Few workers have examined the parasite fauna of wild and stocked trout (Aderounmu, 1966; Wootten, 1973 ; Poynton \& Bennett, 1985 ; McGuigan \& Sommerville, 1985), and none have examined parasite community parameters in any detail. Aderounmu (1966) showed that 12 species were found in wild trout and 7 species were found in hatchery-reared trout. Similarly, Wootten (1973) demonstrated that the parasite fauna of stocked rainbow trout from the raceways in Hanningfield reservoir was a reduced version of the parasite fauna found in the adult fish from the reservoir. In this case prevalence and mean intensity values were provided. Poynton \& Bennett (1985) examined the parasitic infections of wild and cultured brown trout and cultured rainbow trout. This study was more concerned with the identity of parasite species and their potential interactions with cultured fish, rather than parasite community dynamics. McGuigan \& Sommerville (1985) compared the parasite faunas of cultured rainbow trout, eels and wild fish in a eutrophic freshwater loch in the west of Scotland. They demonstrated a number of differences in the prevalence and intensity values recorded for some parasite species between wild and stocked trout. The aim of this study, however, was to examine the effects of intensive fish farming on a Scottish loch in terms of disease and parasites. Correspondingly, sample fish were maintained in cages, artificially fed and treated with therapeutic products when necessary. Therefore the present study is the first, to exclusively examine the parasite infra and component communities of wild and stocked trout living 'freely' in a natural lake. 
Stocked trout were put into Lough Feeagh in late March/early April in each of 2 successive years, giving them about 1 month to acclimatize, and to become infected with parasites before the first fish samples were taken in May. The first parasite species to infect stocked trout in 1997 were the acanthocephalans $A$. clavula and P. laevis. The brown trout is considered to be the preferred definitive host of $P$. laevis in Ireland. In contrast, A. clavula uses the freshwater eel Anguilla anguilla as its preferred definitive host and only occurs occasionally in trout. Both species of acanthocephalan were also the first to infect the stocked trout put into Lough Feeagh in 1998, along with E. crassum and C. farionis which both use trout as their preferred definitive host. The parasite component communities recorded for wild fish in May 1997 and 1998 were richer than those recorded for stocked fish. The parasite component community recorded in stocked fish was made up of the 4 most prevalent species found in wild fish, which agrees with the findings of Hartvigsen \& Halvorsen (1993) who showed that the parasite species infecting recently introduced salmon parr were the most prevalent species in the adjoining lake. The occurrence of the 4 most prevalent species recorded in wild trout, in the stocked trout samples in May 1997 and 1998 also agrees with the findings of Kennedy \& Hartvigsen (2000), who examined the intestinal helminth communities of brown trout from 72 localities in Ireland, England and Norway and identified a group of 4 species which occurred commonly in trout and gave a better degree of predictability to the parasite community. However, in the present study only 3 of the 4 species recorded in May were specialists in trout. The occurrence of E. crassum and C. farionis in stocked trout in May 1998 and not in May 1997 was probably related to a general increase in the abundance of $E$. crassum and C. farionis in Lough Feeagh (as recorded in the in wild trout samples from May 1997 and 1998).

The component communities of wild and stocked trout in August 1997 and 1998 were similar in terms of composition, but different in terms of structure. E. crassum had the lowest component community parameters in stocked trout in May 1998 yet in August it dominated the community. The next most dominant species in stocked trout in August 1998, the larval cestode $D$. ditremum, was absent in May. The increase in the component community parameters of $E$. crassum and D. ditremum was consistent with a peak recruitment period in midsummer (Kennedy, 1996). The dominance of $A$. clavula over $P$. laevis in stocked trout, and the dominance of $P$. laevis over $A$. clavula in wild trout in August suggests that both groups of fish were feeding preferentially on different intermediate hosts, Asellus meridianus in the case of stocked trout and Gammarus duebeni in the case of wild trout. However, O' Grady (1983), working on brown trout in central Ireland, could not find any significant differences in the proportions of Asellus and Gammarus consumed by wild and stocked trout.

Overall the component parasite communities recorded for stocked trout in November 1997 and 1998 were richer than those recorded for wild trout. Only the component community parameters recorded for D. sagittata in 1997, the mean abundance and mean intensity values recorded for $A$. clavula in 1998 and the mean intensity value recorded for $E$. crassum in 1998 were higher for wild trout. The mean abundance and mean intensity values recorded for $E$. crassum in stocked trout in 1997 and 1998 decreased sharply from August to November. This is in agreement with the findings of Kennedy (1996) who demonstrated a large midsummer increase in $E$. crassum as a result of recruitment, followed by a substantial drop. Wyatt \& Kennedy (1988) demonstrated that a number of copepod species had distinct seasonal occurrences, and different species peaked in abundance from spring to autumn. It is likely that a combination of the same seasonal changes in the abundance of copepod intermediate hosts and a significant increase in parasite mortality (and subsequent loss from the fish host) were responsible for the drop in the mean abundance and mean intensity values recorded for E. crassum.

When the total parasite component communities of wild and stocked trout were examined wild trout had the highest prevalence values for 5 of the 10 parasite species they had in common. The composition of the total parasite component community recorded for stocked brown trout was almost identical to that recorded for wild trout; however, in terms of community structure some differences existed between them. Stocked trout had substantially higher prevalence, mean abundance and mean intensity values for $E$. crassum and D. ditremum, and wild trout had higher values for C. farionis. This suggests that stocked trout were feeding on more planktonic organisms, probably planktonic copepods, which are the intermediate hosts of E. crassum and D. ditremum (Kennedy \& Burrough, 1978), and wild trout were feeding on more benthic invertebrates, which are the probable intermediate hosts of C. farionis. A number of studies have examined the diets of wild and stocked fish (Sosiak, Randall \& McKenzie, 1979; O’Grady, 1983; Johnsen \& Ugedal, 1986; Kelly-Quinn \& Bracken, 1989) and all have shown that stocked fish ultimately adopt a normal diet, although the length of time taken to do this differs. Sosiak et al. (1979) working on salmon parr and O'Grady (1983) working on brown trout demonstrated that stocked fish initially favoured food items on or near the surface of the lake. O'Grady (1983) also suggested that competition with resident fish might result in trout being forced from the benthic feeding areas and having to feed near the surface. Thus, stocked fish are considered to 
feed on more items on or near the surface resulting in higher prevalence and mean abundance values for $D$. ditremum and E. crassum.

Few workers have examined helminth infracommunities of fish (Kennedy et al. 1997; Marcogliese \& Cone, 1998; Molloy et al. 1995), similarly, few workers have examined the parasite communities of wild and stocked fish (McGuigan \& Sommerville, 1985; Vidal-Martinez et al. 1998); however, none have compared infracommunity parameters between wild and stocked fish in a natural environment. In both years the infracommunity values recorded for stocked trout reflect the fact that they were only released into Lough Feeagh in late spring. Values for the mean species richness, mean number of individuals, and diversity indices all increased from May to August. Such increases were consistent with the development of the helminth community in stocked trout. The helminth infracommunities of stocked trout in 1997 and 1998 went from being poorer than those recorded for wild trout in May, to being comparable with the infracommunities recorded for wild trout in August, and higher than the infracommunities recorded for wild trout in November.

Vidal-Martinez et al. (1998) compared the parasite communities and presented some infracommunity data for wild and caged C. urophthalmus over a 7month period. A total of 17 parasite species were recorded from the wild fish sample and 10 species were recorded from the caged fish sample. A maximum of 13 parasite species were recorded from the wild fish sample in April. The pattern demonstrated for caged $C$. urophthalmus fish was similar to that demonstrated for stocked trout in Lough Feeagh, in that the number of parasite species increased over the course of the study. However, unlike the situation in Lough Feeagh, the number of parasites recorded in a caged fish in any month never equalled or exceeded the number of parasites recorded in wild fish. This study was also not directly comparable to the study in Lough Feeagh, as stocked C. urophthalmus were fed an artificial diet, and maintained in artificial cages. They had free access to all planktonic copepods and their parasites but not to benthic intermediate hosts. Consequently it would be impossible for caged $C$. uropthalmus to adopt a 'fully wild' parasite fauna.

This study was funded by the Enterprise Ireland applied research grants scheme for universities (Grant He/96/ 131). The authors would also like to acknowledge Mary, Davey, Pat and Eamon of the Marine Institute, for help with all aspects of the fieldwork.

\section{REFERENCES}

ADERounMu, E. A. (1966). A comparative account of the parasite fauna of brown trout Salmo trutta L. from a lake and from a hatchery. Parasitology 56, 10-11p.

BUSh, A. O., LAFFERTY, K. D., LOTZ, J. M. \& ShOSTAK, A. W. (1997). Parasitology meets ecology on its own terms:
Margolis et al. revisited. Fournal of Parasitology 83, 575-583.

BWATHONDI, P. O. J. (1984). The parasites of brown trout Salmo trutta L. in Strathbeg N.E. Scotland. University Science Fournal (Dar University) 10, 131-153.

Byrne, C. J., GRey, C., Holland, C. \& POOle, R. (2000). Parasite community similarity between four Irish lakes. Fournal of Helminthology 74, 301-305.

CONNEEly, J. J. \& McCARThy, T. K. (1988). The metazoan parasites of trout (Salmo trutta) in western Ireland. Polskie Archiwum Hydrobiologii 35, 443-460.

cowx, I. G. (1994). Stocking strategies. Fisheries Management and Ecology 1, 15-31.

CRAGG-HINE, D. (1992). Fish rearing and stocking by the NRA. In Welsh Rivers - Stocking and Taking Stock. Proceedings of the Foint NRA Welsh Region/WSTAA Seminar, University College Aberystwyth, Wales, pp. 46-48.

DORUCU, M., CROMPTON, D. W. T., HUNTINGFORD, F. A. \& WALTERS, D. (1995). The ecology of endoparasitic helminth infections of brown trout (Salmo trutta) and rainbow trout (Oncorhynchus mykiss) in Scotland. Folia Parasitologica 42, 29-35.

hartvigsen, R. \& Halvorsen, o. (1993). Common and rare parasites in a small landscape system.

Parasitology 106, 101-105.

JOHNSEN, B. O. \& UGEDAL, o. (1986). Feeding and hatchery-reared and wild brown trout, Salmo trutta L., in a Norwegian stream. Aquaculture and Fisheries Management 17, 281-287.

KELLY-QUiNN, M. \& BRACKEN, J. J. (1989). A comparison of the diet of wild and stocked hatchery-reared brown trout, Salmo trutta L., fry. Aquaculture and Fisheries Management 20, 325-328.

KENNEDY, C. R. (1996). Establishment, survival and site selection of the cestode Eubothrium crassum in brown trout, Salmo trutta. Parasitology 112, 347-355.

KENNEDy, C. R. \& BURrough, R. J. (1978). Parasites of trout and perch in Malham Tarn. Field Studies 4, 617-629.

KENNEDy, C. R. \& HARTVigsen, R. A. (2000). Richness and diversity of intestinal metazoan communities in brown trout Salmo trutta compared to those of eels Anguilla anguilla in their European heartlands. Parasitology 121, 55-64.

KENNEDY, C. R., DICAVE, D., BERRILli, F. \& ORECCHIA, P. (1997). Composition and structure of helminth communities in eels Anguilla anguilla from Italian coastal lagoons. Fournal of Helminthology 71, 35-40.

KINCAID, H. L. \& CALKINS, G. T. (1992). Retention of visible implant tags in lake trout and Atlantic salmon. Progressive Fish Culturist 54, 163-170.

magurran, A. E. (1988). Ecological Diversity and its Measurement. Chapman and Hall, London.

MARCogliese, D. J. \& CONE, D. K. (1998). Comparison of richness and diversity of macroparasite communities among eels from Nova Scotia, the United Kingdom and Australia. Parasitology 116, 73-83.

MatTheWs, M. A., POOLE, W. R., Dillane, M. G. \& WHELAN, K. F. (1997). Juvenile recruitment and smolt output of brown trout (Salmo trutta L.) and Atlantic salmon (Salmo salar L.), from a lacustrine system in western Ireland. Fisheries Research 31, 19-37. 
McGuigan, J. B. \& Sommerville, C. (1985). Studies on the effects of cage culture of fish on the parasite fauna in a lowland freshwater loch in the west of Scotland. Zeitschrift fur Parasitenkunde 71, 673-682.

Molloy, s., Holland, C. \& POOLE, R. (1995). Metazoan parasite community structure in brown trout from two lakes in western Ireland. Fournal of Helminthology 69, 237-242.

O'GRADY, M. F. (1983). Observations on the dietary habits of wild and stocked brown trout, Salmo trutta L., in Irish lakes. Fournal of Fish Biology 22, 593-601.

Sosiak, A. J., RANDALl, R. G. \& MCKENZIE, J. A. (1979).

Feeding by hatchery-reared and wild Atlantic salmon parr in streams. Fournal of the Fisheries Research Board of Canada 36, 1408-1412.

POynton, S. L. \& BennetT, C. E. (1985). Parasitic infections and their interactions in wild and cultured brown trout and cultured rainbow trout from the river Itchen, Hampshire. In Fish and Shellfish Pathology (ed. Ellis, A. E.), pp. 353-357. Academic Press, London.

VIDAL-MARTINEZ, V. M., KENNEDY, C. R. \& AGUIRREMACEDO, M. L. (1998). The structuring process of the macroparasite community of an experimental population of Cichlasoma urophthalmus through time. Fournal of Helminthology 72, 199-207.

wootten, R. (1973). The metazoan parasite-fauna of fish from Hanningfield Reservoir, Essex in relation to features of the habitat and host populations. Fournal of Zoology 171, 323-331.

WYATT, R. J. \& KENNEDY, C. R. (1988). The effects of a change in the growth rate of roach, Rutilus rutilus (L.), on the biology of the fish tapeworm Ligula intestinalis (L.). Fournal of Fish Biology 33, 45-57. 